the quantity of each description-has just been published, of which the following is a summary:-

\begin{tabular}{lrr} 
& Ships. & \multicolumn{1}{c}{ Tons. } \\
Newcastle coal, & 1871 & 631,884 \\
Ditto Wall's End, & 1724 & 505,153 \\
Sunderland coal & 45 & 13,693 \\
Ditto Wall's End, & 2329 & 684,680 \\
Stockton coal, & 16 & 3,107 \\
Ditto Wall's End, & 1963 & 518,813 \\
Srotch, & 148 & 12,108 \\
Yorkshire, & 712 & 71,034 \\
Small coal, & 15 & 4,127 \\
Welsh, & 307 & 79,924 \\
Blyth, & 421 & 98,622 \\
Sundry places, & 2 & 190 \\
\multicolumn{1}{c}{ Totals, } & $\mathbf{9 5 5 3}$ & $\mathbf{2 , 6 2 3 , 3 3 5}$
\end{tabular}

Of culm there has been imported, in 9 ships, 1801 tons; and of cinders, in 31 ships, 3384 tons-making an aggregate total of 9593 ships, and 2,628,520 tons. 'These returns show a falling off, (as compared with 1841, in which was sold in the London market $2,909,144$ tons-the largest quantity ever imported in one year,) of 270,624 tons; and, as the above quantity averages about 270 tons per cargo, it may be estimated that 1000 coal vessels, or about one-tenth, have been unemployed in that trade during 1843, which were so employed in the year 1841. In 1842, the quantity was intermediate - viz., $2,723,200$ tons-showing a gradual decrease; and it would be an interesting inquiry to ascertain the cause of such diminution of consumption, with a two years' increase of population, probably 100,000, and how far it may be connected with the stagnant state of trade-the want of employment, and consequent distress of the people.

Lond. Mining Journ.

On the principal cause of the Rocking Motion of Lacomotive Engines and Carriages. By G. Heatax.

Mr. G. Heaton's paper "On the principal cause of the rocking motion of Locomotive Engines and Carriages," wras read January 31st, and several experiments, with machines made for the purpose, were shown by way of illustration.

Mr. Heaton's attention was first drawn to the subject early in the year 1838, when employed to examine a steam engine and machinery used for making boiler plates, rolled bars, \&c. He found that the fly wheels of the ongine, when revolving rapidly, made a very rumbling noise, and the lighter one would jump as high as the glad would let it ; indeed, the whole building rocked when the machinery was in motion. It was found that the fly wheels were beavy sided, and that the smaller one, 16 feet in diameter, required $160 \mathrm{lbs}$. on one side, and the larger one, 18 feet in diameter, $322 \mathrm{lbs}$. to equipoise them. This having been done, the whole of the machinery moved easily 
and quietly. This result caused the author to turn his attention to the rocking and jumping motion experienced in locomotive engines and carriages. The difference of speed at which the different parts of a wheel in motion progress, or the speed at which bodies descend through short distances, does not appear to have been taken sufficient notice of by engineers, as the heavy side of a wheel has to fall at certain intervals during its revolution sixty times as fast as it would fall by gravity alone. When a railway engine is traveling at the rate of 33 miles per hour, the top of its wheel is thrown forward at the rate of about 92 feet, and downward at the rate of 46 feet in a second. Railway carriage wheels are frequently 6 to $7 \mathrm{lbs}$. heavier on one side than on the other: it is no wonder, therefore, that the unpleasant motion experienced while traveling in carriages so circumstanced, is so often complained of. Without entering into detail with regard to the different machines used for the purpose of illustrating $\mathrm{Mr}$. Heaton's views, it may be well to describe the most simple one, and the method of making the experiments. The model is made to represent the wheels and axle of a railway carriage, the axle being 16 inches long, and the wheels $6 \frac{1}{4}$ inches diameter. By placing some loose pieces of iron inside the rims, so as to represent wheels which are $\frac{1}{6}$ th of an inch thicker on one side than the other, the thick side of one wheel being placed opposite the thick side of the other, at the opposite ends of the axle, according to the common practice, and the wheels allowed to revolve, the model will continue to jump about the table, on which it is placed, so long as the wheels are in motion. Again, if the pieces of iron be all placed on the same side of the centre, the model will not rock as before, but jump up and down, and make more evolutions than in the last case. The wheels being perfectly equilibrated, will revolve without any oscillating movement, and the frame remain quite steady, the number of revolutions, with the same power, being considerably increased. The paper was accompanied by tables, showing the effects produced by the experiments made under different circumstances.

February 14.-Mr. Heaton continued his experiments illustrative of the principal cause of the rocking motion of railway engines and carriages. The machine by which these experiments were shown, consists of a cam ring, having four sets of cams on its periphery, viz., one set of sixteen cams, one set of eight cams, one set of four cams, and one set of two cams. When the cam ring is made to revolve, the cams raise a rod of iron 12 inches long, and supported at one end by a cross bar fixed between the centres; when the rod is fixed for the sixteen cams, it is raised three-fourth of an inch by each cam, and strikes (after the manner of a forge hammer) 292 blows per minute, or travels at the rate of $7 \frac{1}{3}$ inches in a second, and no faster. When fixed for eight cams, to raise it 12 inch high, the rod strikes 224 blows per minute, or travels at the rate of $11 \frac{1}{\mathrm{~s}}$ inches per second. When fixed for four cams, to raise it 3 inches high, the rod will strike 170 blows per minute, or travel at the rate of 17 inches per second-a half pound weight being fixed close to the end of the rod which is raised by the cam, two additional blows will be struck in one minute 
more than when the rod is not thus loaded-and if the half pound weight be removed, and a two pound weight be fixed near to the centre of the rod, so as to require the same weight to raise it by each cam, it will strike 233 blows in a minute, or travel at the rate of $25 \frac{1}{5}$ inches in one second, showing that the one end of the rod working on the centres does not retard the falling of the rod lifted by each cam. Other experiments were made with the same machine with modifications, from which it appears that the small iron rod travels as fast as a forge hammer ordinarily used-that the velocity of a body falling short distances, is doubled when passing through double the distancethat allowance should be made for the momentum of the piston, piston-rod, and slide of a locomotive engine-and showing that a great loss of power is sustained by the wheels being heavy sided.-Trans. Soc. Arts.

Lond. Athenæum.

\section{The Liverpool Screw.}

A paper by Mr. J. Grantham, was read February 13th, describing a series of experiments on an iron vessel called the Liverpool Screw: This boat was 65 feet long, 12 feet 6 inches beam, and had 3 feet 9 inches draught of water. She was propelled by two high pressure oscillating engines, with cylinders 13 inches diameter, and 18 inches stroke. The pressure of the steam in the boiler varied from $50 \mathrm{lbs}$. to $60 \mathrm{lbs}$. per square inch; and it was cut off at one-fourth of the length of the stroke, working the remainder by expansion. The nominal power was 20 horses, but it did not really exceed $18 \frac{1}{2}$ horses. The cylinders were placed diagonally, with both the piston rods working upon the same crank; the driving shaft being beneath the cylinders, and running direct to the propeller, without the intervention of either gearing, or bands. The screw propeller was enlarged three times, and, at last, was left at 5 feet 4 inches diameter by 20 inches in length. It was set out with a pitch expanding from 10 to 11 feet, on Woodcroft's plan. It was made of wrought-iron, with four short arms with broad shovel ends, whose united area was 16 square feet, 13 feet only of it being immersed, as some portion of the arms was constantly above water. The angle of the centre of the float was $45^{\circ}$. The speed of the propeller was generally 95 revolutions per minute. With these dimensions, the speed attained was described as $10 \frac{1}{2}$ statute miles per hour. The amount of "slip" of the screw in the water, as ascertained by Massey's log, was stated not to exceed 5 per cent. Several experiments were detailed, which showed that there was not more tendency to "list," or to turn round, by the action of the screw, than with paddle wheels; and the vessel was said to have excelled all the other steamers of the port of Liverpool, in towing out vessels in a rough sea. Designs were submitted on this principle for a steam frigate, and for large steamers, working with oscillating cylinders direct upon the main shaft.

February 20.-The discussion on the "screw propeller" was re- 